\title{
Diallel analysis of corn for special use as corn grits: determining the main genetic effects for corn gritting ability
}

T.V. Conrado ${ }^{1}$, C.A. Scapim 1 , L.S. Bignotto 1 , R.J.B. Pinto ${ }^{1}$, I.L.J. Freitas ${ }^{2}$, A.T. Amaral Jr. ${ }^{2}$ and A.C. Pinheiro ${ }^{1}$

'Departamento de Agronomia, Universidade Estadual de Maringá, Maringá, PR, Brasil

${ }^{2}$ Universidade Estadual do Norte Fluminense Darcy Ribeiro,

Campos dos Goytacazes, RJ, Brasil

Corresponding author: A.T. Amaral Jr.

E-mail: amaraljr@pq.cnpq.br

Genet. Mol. Res. 13 (3): 6548-6556 (2014)

Received July 11, 2014

Accepted July 30, 2014

Published August 26, 2014

DOI http://dx.doi.org/10.4238/2014.August.26.5

\begin{abstract}
Corn grits are used for various purposes such as flakes, snacks, livestock feed, hominy, extruded products, beer, etc. The grit size proportion varies according to the hybrid, and thus, once the use of the grits is linked to the particle size, determining the genetic effects is essential to develop hybrids for any specific use. For this purpose a complete diallel series of crosses, involving eight parents, was performed near Maringá, PR, Brazil. The objective of this study was to evaluate the general (GCA) and specific (SCA) combining abilities of 28 progeny for selection of hybrids for breeding programs and extraction of inbred lines for hybrid development. The response variables, such as plant height, ear insertion height, crop stand, grain yield, and grits, small grits and bran production, were gauged and appraised for each of the 28 progeny. The trait effects and GCA were significant for all response variables, while for SCA, only grain yield and crop stand showed significance $(\mathrm{P}<$ 0.05), according to Griffing (1955) analysis. A significant weak negative
\end{abstract}


partial correlation was found between grain yield and grits conversion. In relation to the hybrid selection for breeding programs, the parent IAC Nelore was highly recommended for recurrent selection and the hybrids IPR 119 x HT 392 and IAC Nelore x HD 332 for the extraction of pure lines for hybrid development.

Key words: Grits; Griffing; Hybrids; Partial correlation; Breeding; Specific combining ability; General combining ability

\section{INTRODUCTION}

Corn grits is the name for hulled corn kernels, fully or partially degerminated (Castro et al., 2009). They are commonly used in the preparation of typical desserts, livestock feed, snacks, corn flakes, beer, extruded foods, and general foods. However the particle size is defined according to their purpose.

Occasionally, corn grits are misclassified as a special kind of corn, such as white corn, sweet corn and popcorn. The right classification is according to the special use of corn, such as silage, corn for oil extraction or food for fresh consumption.

Despite the importance of obtaining cultivars with high germination and vigor, there have been few studies on the genetic effects of the predominant characteristics associated with seed quality in hominy corn. Accordingly, the study of combining ability can provide valuable information, since it allows the selection of the most promising traits for obtaining parental hybrids with higher quality of seeds on the basis of their general (GCA) and specific (SCA) combining abilities and reciprocal effect (Griffing, 1955).

Moterle et al. (2012) studied combining ability for seed quality in nine popcorn strains in a complete diallel without reciprocals, and observed that the estimates of GCA and SCA were significant for germination, first count, accelerated aging, modified cold, electrical conductivity, seedling emergence in sand, speed of emergence, and emergence rate.

Cabral et al. (2013), in studying the genetic effects of seed quality in diallel in popcorn, found that there was genetic variability for seed quality between strains, where there was a non-additive genetic effect for predominant seed quality, and that there was a prononuced reciprocal effect for seed quality in popcorn, necessitating early indication of male and female parents in crosses.

A great number of studies about corn combining ability have been carried out. Recently, diallel analyses have been used to select parents for local breeding programs (Paini et al., 1996; Pfann et al., 2009) or even to infer about heredity and reciprocal effect (Ünay et al., 2004). Studies to evaluate SCA in corn have reported significant differences between traits, besides a predominance of non-additive effects for corn yield (Teixeira et al., 2001; Scapim et al., 2002).

Concerning the special uses of corn, several studies have been conducted. Rodrigues et al. (2009), from a complete diallel with eight lines, indicated corn hybrids for fresh consumption and concluded that the characteristic color is controlled mainly by additive effects, while the length and cob diameter are more often controlled by non-additive genetic effects, also reaffirming the importance of heterosis in grain yield.

A diallel analysis performed to determine the behavior of the oil content in ten maize populations and their respective hybrids was conducted by Mittelmann et al. (2006). As a 
result, heterosis was observed with dominance in the direction of reducing the existing levels, and from this finding, recurrent selection was recommended to promote the accumulation of genes with additive effect.

To analyze the genetic mechanisms of corn for use as silage, Gomes et al. (2000) conducted a diallel with six parents and their hybrids to determine the in situ dry matter digestibility (ISDMD) and noted the predominance of additive effects, thereby recommending the use of parents with high GCA for ISDMD, which increases heterosis for grain yield.

This study aimed to evaluate the GCA and SCA of 28 progeny for selection of hybrids indicated in breeding and extraction of inbred lines for hybrid development programs.

\section{MATERIAL AND METHODS}

This study was conducted at the Iguatemi Experimental Farm, afforded by Universidade Estadual de Maringá, in the district of Maringá, Paraná State, Brazil. The growing area lies 510 meters above sea level, has a sprinkler irrigation system and a high fertility and chemically balanced soil, and can handle two annual crops. The soil is classified as eutrophic red-yellow argisol. The more superficial layer is known as Caiuá sandstone followed by basalt rocks at about 30 feet deep.

Among the eight hybrid parents, three were white flint commercial types: IPR 119, double-cross hybrid; IPR 127, single-cross hybrid; and IAC Nelore, an intervarietal hybrid. The last five parents were experimental hybrids: the double-cross yellow flint hybrid HD 332 and the three-way yellow dent hybrids HT 932, HT 9332, HT 5392, and HT 392.

The parents were sown promoting the 28 possible pairwise combinations on May 5 , 2009. The planting rows were spaced at $0.9 \mathrm{~m}$ apart, with $10 \mathrm{~m}$ in length for each parent, with 55 seeds per row. Fertilizer with a 04-14-08 formulation was applied at $330 \mathrm{~kg} / \mathrm{ha}$. Irrigation was performed whenever necessary. Ammonium sulfate was applied as nitrogen source, 30 days after emergence. The management of pests and weeds was carried out continuously in order to ensure good seed production. The harvest of grain was held putting both reciprocals together on August 5, 2009.

The 28 hybrids were conducted in randomized complete block design with three replications. The plot was two rows of 15 feet, spaced at $0.9 \mathrm{~m}$, with a density of 5.5 plants per meter. The seeds were sown on October 22, 2009; at stage 6, the plant height and ear insertion measurement was performed, together with the plant count per plot. The gathering process was started at on March 22, 2010, collecting a full repetition per day. Each harvested cross was mechanically threshed and had its mass and humidity measured and corrected on the same date of grits processing. A sample of $10 \mathrm{~kg}$ from each plot was processed in the drum type gritting processor for $5 \mathrm{~min}$. The mass was processed separately using Tyler 5 and Tyler 14 sieves, with openings of 4 and $1.18 \mathrm{~mm}$, respectively. The hybrid conversion capabilities were defined by three fractions: grits, small grits and bran. The mass of each fraction was corrected for base moisture of $13 \%$. Data were subjected to analysis of normality, homoscedasticity and additive presumption, using the following tests: Shapiro and Wilk, Brown and Forsythe and Tukey, also including histogram analysis and data scatter plot to validate their tests. Afterwards, analysis of variance, analysis of Pearson's correlations devoid of the effect of stand harvest, the Fisher least significant difference test ranked by Fasoulas (1983) were carried out, followed by diallel analysis according to Griffing (1955), using a fixed model in method 1 to obtain GCA and SCA. 


\section{RESULTS AND DISCUSSION}

The datasets for the seven observed response variables showed a distribution that did not differ significantly from a normal distribution, and they all exhibited homoscedasticity of variances and model additivity. The analysis of variance inferred all variables as significant at the 0.05 level.

The experimental data allowed the formation of a large number of groups, from the result of the LSD test, described in Table 1. For the variable height of plant, the hybrids IPR 119 x IPR 127, IPR 119 x HT 5392, HD 332 x HT 9332, HT 9332 x HT 5392, and HT 9332 x IPR 119 did not differ significantly from each other, and the first four were superior to 11 materials; IPR 119 x HT 332, in turn, was significantly better than thirteen materials when considering the shorter plants as being desired.

\begin{tabular}{|c|c|c|c|c|c|c|c|c|}
\hline \multirow{2}{*}{$\begin{array}{l}\text { Hybrid } \\
\text { IPR } 119 \text { x IPR } 127\end{array}$} & \multicolumn{2}{|c|}{ Plant height (m) } & \multicolumn{2}{|c|}{ Ear height (m) } & \multicolumn{2}{|c|}{ Crop stand (unit) } & \multicolumn{2}{|c|}{ Yield (kg/ha) } \\
\hline & $2.17^{\mathrm{hi}}$ & $0 \%$ & $1.12^{\text {efghij }}$ & $0 \%$ & $104.00^{\text {fghi }}$ & $7 \%$ & $3457.37^{\text {efgh }}$ & $0 \%$ \\
\hline IPR $119 \times$ IAC Nelore & $2.50^{\mathrm{ab}}$ & $61 \%$ & $1.22^{\text {bcdefg }}$ & $11 \%$ & $96.33^{\mathrm{ijk}}$ & $4 \%$ & $3719.95^{\text {defgh }}$ & $0 \%$ \\
\hline IPR 119 x HT 932 & $2.25^{\mathrm{fghi}}$ & $0 \%$ & $1.14^{\text {defghij }}$ & $0 \%$ & $99.33^{\mathrm{hi}}$ & $7 \%$ & $4079.39^{\text {cdef }}$ & $14 \%$ \\
\hline IPR $119 \times$ HD 332 & $2.20^{\text {ghi }}$ & $0 \%$ & $1.12^{\text {efghij }}$ & $0 \%$ & $83.00^{\mathrm{jk}}$ & $4 \%$ & $3165.48^{\mathrm{h}}$ & $0 \%$ \\
\hline IPR 119 x HT 9332 & $2.11^{\mathrm{i}}$ & $0 \%$ & $1.08^{\mathrm{ij}}$ & $0 \%$ & $120.67^{\text {bcde }}$ & $32 \%$ & $3744.00^{\text {defgh }}$ & $0 \%$ \\
\hline IPR 119 x HT 5392 & $2.16^{\mathrm{hi}}$ & $0 \%$ & $1.16^{\text {defghij }}$ & $0 \%$ & $80.67^{\mathrm{k}}$ & $0 \%$ & $3129.99^{\mathrm{h}}$ & $0 \%$ \\
\hline IPR 119 x HT 392 & $2.37^{\text {bcdef }}$ & $25 \%$ & $1.21^{\text {cdefghi }}$ & $4 \%$ & $115.33^{\text {cdefgh }}$ & $14 \%$ & $4532.94^{a b c}$ & $46 \%$ \\
\hline IPR 127 x IAC Nelore & $2.44^{\text {abcde }}$ & $43 \%$ & $1.27^{\mathrm{abcd}}$ & $29 \%$ & $116.00^{\text {cdefg }}$ & $18 \%$ & $3591.52^{\mathrm{efgh}}$ & $0 \%$ \\
\hline IPR 127 x HT 932 & $2.19^{\text {ghi }}$ & $0 \%$ & 1.09 ghij & $0 \%$ & $111.00^{\text {defghi }}$ & $7 \%$ & $3249.80^{\mathrm{gh}}$ & $0 \%$ \\
\hline IPR 127 x HD 332 & $2.29^{\text {cdefgh }}$ & $4 \%$ & $1.17^{\text {defghij }}$ & $0 \%$ & $120.33^{\text {bcde }}$ & $32 \%$ & $3950.76^{\text {cdefg }}$ & $11 \%$ \\
\hline IPR 127 x HT 9332 & $2.36^{\text {bcdefg }}$ & $18 \%$ & $1.21^{\text {cdefghi }}$ & $4 \%$ & $116.67^{\text {cdefg }}$ & $18 \%$ & $3381.32^{\mathrm{fgh}}$ & $0 \%$ \\
\hline IPR 127 x HT 5392 & $2.23^{\text {fghi }}$ & $0 \%$ & $1.18^{\text {defghij }}$ & $0 \%$ & $118.00^{\text {bcdef }}$ & $21 \%$ & $3576.91^{\text {efgh }}$ & $0 \%$ \\
\hline IPR 127 x HT 392 & $2.36^{\text {bcdefg }}$ & $18 \%$ & $1.22^{\text {bcdefgh }}$ & $7 \%$ & $133.67^{\mathrm{ab}}$ & $61 \%$ & $3748.35^{\text {defgh }}$ & $0 \%$ \\
\hline IAC Nelore x HT 932 & $2.55^{\mathrm{a}}$ & $75 \%$ & $1.35^{\mathrm{ab}}$ & $57 \%$ & $133.00^{\mathrm{ab}}$ & $61 \%$ & $4676.26^{\mathrm{abc}}$ & $46 \%$ \\
\hline IAC Nelore x HD 332 & $2.58^{\mathrm{a}}$ & $75 \%$ & $1.36^{\mathrm{a}}$ & $79 \%$ & $134.00^{\mathrm{ab}}$ & $61 \%$ & $5034.78^{\mathrm{a}}$ & $71 \%$ \\
\hline IAC Nelore x HT 9332 & $2.45^{\text {abcd }}$ & $50 \%$ & $1.31^{\mathrm{abc}}$ & $50 \%$ & $130.00^{\mathrm{abc}}$ & $46 \%$ & $4942.88^{\mathrm{a}}$ & $71 \%$ \\
\hline IAC Nelore x HT 5392 & $2.51^{\mathrm{ab}}$ & $61 \%$ & $1.34^{\mathrm{abc}}$ & $50 \%$ & $105.00^{\text {efghi }}$ & $7 \%$ & $4169.19^{\text {bcde }}$ & $18 \%$ \\
\hline IAC Nelore x HT 392 & $2.47^{\mathrm{abc}}$ & $54 \%$ & $1.24^{\mathrm{abcde}}$ & $18 \%$ & $122.33^{\mathrm{abcd}}$ & $32 \%$ & $4417.59^{\mathrm{abcd}}$ & $32 \%$ \\
\hline HT $932 \times$ HD 332 & $2.24^{\mathrm{fghi}}$ & $0 \%$ & $1.12^{\text {efghij }}$ & $0 \%$ & $110.67^{\text {defghi }}$ & $7 \%$ & $3426.79^{\text {efgh }}$ & $0 \%$ \\
\hline HT 932 x HT 9332 & $2.28 \mathrm{e}^{\text {fghi }}$ & $0 \%$ & $1.18^{\text {defghij }}$ & $0 \%$ & $111.00^{\text {defghi }}$ & $7 \%$ & $4122.42^{\text {bcdef }}$ & $14 \%$ \\
\hline HT 932 x HT 5392 & $2.26 \mathrm{e}^{\mathrm{fghi}}$ & $0 \%$ & $1.18^{\text {defghij }}$ & $0 \%$ & $105.33^{\text {efghi }}$ & $7 \%$ & $3711.08^{\text {defgh }}$ & $0 \%$ \\
\hline HT 932 x HT 392 & $2.23^{\text {fghi }}$ & $0 \%$ & $1.10^{\text {fghij }}$ & $0 \%$ & $97.67^{\mathrm{ij}}$ & $4 \%$ & $3130.56^{\mathrm{h}}$ & $0 \%$ \\
\hline HD $332 \times$ HT 9332 & $2.16^{\mathrm{hi}}$ & $0 \%$ & $1.09^{\text {hij }}$ & $0 \%$ & $109.33^{\text {defghi }}$ & $7 \%$ & $4047.76^{\text {cdef }}$ & $11 \%$ \\
\hline HD $332 \times$ HT 5392 & $2.32^{\text {cdefgh }}$ & $4 \%$ & $1.23^{\text {bcdef }}$ & $14 \%$ & $115.33^{\text {cdefgh }}$ & $14 \%$ & $4454.86^{\mathrm{abcd}}$ & $32 \%$ \\
\hline HD $332 \times$ HT 392 & $2.36^{\text {bcdefg }}$ & $18 \%$ & $1.22^{\text {bcdefg }}$ & $11 \%$ & $120.00^{\text {bcdef }}$ & $21 \%$ & $3969.02^{\text {cdefg }}$ & $11 \%$ \\
\hline HT $9332 \times$ HT 5392 & $2.17^{\mathrm{hi}}$ & $0 \%$ & $1.06^{\mathrm{j}}$ & $0 \%$ & $101.00^{\mathrm{ghi}}$ & $7 \%$ & $4171.55^{\text {bcde }}$ & $18 \%$ \\
\hline HT $9332 \times$ HT 392 & $2.26^{\text {ghhi }}$ & $0 \%$ & $1.21^{\text {cdefghi }}$ & $4 \%$ & $138.33^{\mathrm{a}}$ & $75 \%$ & $4667.20^{\mathrm{abc}}$ & $46 \%$ \\
\hline HT $5392 \times$ HT 392 & $2.29^{\text {defghi }}$ & $0 \%$ & $1.23^{\text {bedef }}$ & $14 \%$ & $130.67^{\mathrm{abc}}$ & $46 \%$ & $4871.12^{\mathrm{ab}}$ & $61 \%$ \\
\hline
\end{tabular}

Means with the same superscript letters do not differ significantly with $\alpha=0.05$ and the percentage indicates the amount of materials significantly outnumbered.

Regarding ear insertion height, the IAC Nelore x HD 332 differed from 22 hybrids, while the HT 9332 x HT 5392 differed significantly from another 14 materials, showing the lowest ear insertion height. It should be noted that a lower center of gravity is preferable, and therefore, the hybrids with lower ear insertion height were defined as superior.

On the subject of the response variable crop stand, the HT 9332 x HT 392 was highlighted with superior average over $75 \%$ of hybrids, according to the method of Fasoulas (1983). In contrast, IPR 119 x HT 5392 did not significantly exceed any other hybrid. 
Concerning productivity, two crosses involving the parent IAC Nelore, surpassed the average yield of $71 \%$ of hybrids: IAC Nelore x HD 332 and IAC Nelore x HT 9332. It is interesting to note that the former showed a higher or not significantly different average when compared to all other materials in all four of the agronomic characteristics evaluated $(\mathrm{P}>$ 0.05). Similar behavior was exhibited by hybrids IAC Nelore x 9332 HD, IAC Nelore x HD 932 and Nelore IAC x HD 392.

However, this behavior is not the most desirable, since it is expected that modern hybrids are smaller and have a lower ear height, like HT 5392 x HT 392 and HT 9332 x HT 392. These hybrids were significantly smaller and had a lower ear insertion height compared to IAC Nelore x HD 332, IAC Nelore x HD 9332, IAC Nelore x HD 932 and IAC Nelore x HD 392, but they showed stand and productivity that were not significantly different, with $\alpha=0.05$. For HT 9332 x HT 392, was not significantly different from that of genotypes with greater conversion of grain into grits, as shown in Table 2.

\begin{tabular}{|c|c|c|c|c|c|c|}
\hline \multirow{2}{*}{$\begin{array}{l}\text { Hybrid } \\
\text { IPR } 119 \text { x IPR } 127\end{array}$} & \multicolumn{2}{|c|}{ Grits conversion (\%) } & \multicolumn{2}{|c|}{ Small grits conversion $(\%)$} & \multicolumn{2}{|c|}{ Bran conversion $(\%)$} \\
\hline & $66.99^{\text {abcdef }}$ & $7 \%$ & $5.19^{\text {defghi }}$ & $0 \%$ & $25.23^{\text {cdef }}$ & $0 \%$ \\
\hline IPR 119 x IAC Nelore & $60.43^{\mathrm{h}}$ & $0 \%$ & $7.17^{\mathrm{a}}$ & $43 \%$ & $30.32^{\mathrm{a}}$ & $64 \%$ \\
\hline IPR 119 x HT 932 & $64.47^{\text {cdefgh }}$ & $0 \%$ & $6.00^{\text {abcdefg }}$ & $14 \%$ & $27.20^{\text {abcde }}$ & $4 \%$ \\
\hline IPR 119 x HD 332 & $65.97^{\text {abcdefg }}$ & $4 \%$ & $6.22^{\text {abcdef }}$ & $14 \%$ & $26.37^{\text {cdef }}$ & $0 \%$ \\
\hline IPR 119 x HT 9332 & $66.81^{\text {abcdef }}$ & $7 \%$ & $6.72^{\mathrm{abcd}}$ & $21 \%$ & $25.27^{\text {cdef }}$ & $0 \%$ \\
\hline IPR 119 x HT 5392 & $64.73^{\text {bcdefgh }}$ & $0 \%$ & $5.27^{\text {cdefghi }}$ & $0 \%$ & $28.25^{\mathrm{abc}}$ & $18 \%$ \\
\hline IPR 119 x HT 392 & $64.00^{\text {defgh }}$ & $0 \%$ & $5.70^{\text {abcdefghi }}$ & $0 \%$ & $28.10^{\mathrm{abcd}}$ & $14 \%$ \\
\hline IPR 127 x IAC Nelore & $67.32^{\text {abcdef }}$ & $7 \%$ & $4.17^{\mathrm{i}}$ & $0 \%$ & $25.92^{\text {cdef }}$ & $0 \%$ \\
\hline IPR 127 x HT 932 & $71.26^{\mathrm{a}}$ & $46 \%$ & $4.41^{\text {ghi }}$ & $0 \%$ & $23.24^{\mathrm{f}}$ & $0 \%$ \\
\hline IPR 127 x HD 332 & $67.20^{\mathrm{abcdef}}$ & $7 \%$ & $5.35^{\text {bcdefghi }}$ & $0 \%$ & $25.55^{\text {cdef }}$ & $0 \%$ \\
\hline IPR 127 x HT 9332 & $68.27^{\text {abcde }}$ & $11 \%$ & $4.16^{\mathrm{i}}$ & $0 \%$ & $25.20^{\text {cdef }}$ & $0 \%$ \\
\hline IPR 127 x HT 5392 & $67.56^{\text {abcdef }}$ & $7 \%$ & $4.68^{\text {fghi }}$ & $0 \%$ & $25.98^{\text {cdef }}$ & $0 \%$ \\
\hline IPR 127 x HT 392 & $70.07^{\mathrm{ab}}$ & $32 \%$ & $4.92^{\text {efghi }}$ & $0 \%$ & $23.52^{\mathrm{ef}}$ & $0 \%$ \\
\hline IAC Nelore x HT 932 & $65.63^{\text {bcdefgh }}$ & $0 \%$ & $5.32^{\text {bcdefghi }}$ & $0 \%$ & $27.12^{\text {abcde }}$ & $4 \%$ \\
\hline IAC Nelore $\mathrm{x}$ HD 332 & $65.15^{\text {bcdefgh }}$ & $0 \%$ & $5.72^{\text {abcdefghi }}$ & $0 \%$ & $26.65^{\text {abcdef }}$ & $0 \%$ \\
\hline IAC Nelore x HT 9332 & $69.50^{\mathrm{abc}}$ & $21 \%$ & $4.27^{\mathrm{hi}}$ & $0 \%$ & $24.10^{\mathrm{ef}}$ & $0 \%$ \\
\hline IAC Nelore x HT 5392 & $65.62^{\text {bcdefgh }}$ & $0 \%$ & $5.58^{\text {abcdefghi }}$ & $0 \%$ & $25.93^{\text {cdef }}$ & $0 \%$ \\
\hline IAC Nelore x HT 392 & $64.60^{\text {cdefgh }}$ & $0 \%$ & $5.80^{\text {abcdefghi }}$ & $0 \%$ & $26.70^{\text {abcdef }}$ & $0 \%$ \\
\hline HT 932 x HD 332 & $67.35^{\text {abcdef }}$ & $7 \%$ & $5.13^{\text {defghi }}$ & $0 \%$ & $23.90^{\mathrm{ef}}$ & $0 \%$ \\
\hline HT 932 x HT 9332 & $64.22^{\text {cdefgh }}$ & $0 \%$ & $6.42^{\mathrm{abcde}}$ & $18 \%$ & $26.93^{\text {abcdef }}$ & $0 \%$ \\
\hline HT 932 x HT 5392 & $65.97^{\text {abcdefg }}$ & $4 \%$ & $5.92^{\text {abcdefgh }}$ & $7 \%$ & $26.35^{\text {cdef }}$ & $0 \%$ \\
\hline HT 932 x HT 392 & $69.17^{\mathrm{abcd}}$ & $14 \%$ & $5.26^{\text {cdefghi }}$ & $0 \%$ & $24.49^{\text {def }}$ & $0 \%$ \\
\hline HD $332 \times$ HT 9332 & $67.60^{\text {abcdef }}$ & $7 \%$ & $5.58^{\text {abcdefghi }}$ & $0 \%$ & $24.97^{\text {cdef }}$ & $0 \%$ \\
\hline HD 332 x HT 5392 & $63.65^{\text {efgh }}$ & $0 \%$ & $6.95^{\mathrm{abc}}$ & $29 \%$ & $26.12^{\text {cdef }}$ & $0 \%$ \\
\hline HD $332 \times$ HT 392 & $63.97^{\text {defgh }}$ & $0 \%$ & $7.00^{\mathrm{ab}}$ & $36 \%$ & $26.47^{\text {bcdef }}$ & $0 \%$ \\
\hline HT 9332 x HT 5392 & $62.78^{\mathrm{fgh}}$ & $0 \%$ & $6.72^{\mathrm{abcd}}$ & $21 \%$ & $28.12^{\mathrm{abcd}}$ & $14 \%$ \\
\hline HT 9332 x HT 392 & $66.05^{\text {abcdefg }}$ & $4 \%$ & $5.92^{\text {abcdefgh }}$ & $7 \%$ & $26.25^{\text {cdef }}$ & $0 \%$ \\
\hline HT 5392 x HT 392 & $61.13^{\mathrm{gh}}$ & $0 \%$ & $6.80^{\mathrm{abcd}}$ & $21 \%$ & $30.15^{\mathrm{ab}}$ & $61 \%$ \\
\hline
\end{tabular}

Hybrid means with the same superscript letters do not differ significantly with $\alpha=0.05$ and the percentage indicates often the hybrid was featured as superior.

Table 2 gives the results of the LSD test for the response variables of industrial interest. Selecting hybrids with higher capacity of gritting conversion is a valid assumption only for certain purposes such as the production of cereals or marketing as hominy; other purposes such as production of oil or beer, hybrids with larger small grits fraction, in most cases, are more interesting.

This assumption is validated by the pricing of those products, since typically the three products (grits, small grits and bran) have similar market values, guided by corn grain value. 
There were fifteen materials that did not differ significantly $(\mathrm{P}<0.05)$ with respect to their grits average, showing high values: IPR 127 x HT 932, IPR 127 x HT 392, IAC Nelore x HT 9332, HT 932 x HT 392, IPR 127 x HT 9332, HD 332 x HT 9332, IPR 127 x HT 5392, HT 932 x HD 332, IPR 127 x IAC Nelore, IPR 127 x HD 332, IPR 119 x IPR 127, IPR 119 x HT 9332, HT 9332 x HT 392, IPR 119 x HD 332, and HT 932 x HT 5392. These hybrids had an average conversion rate between 66 and $71 \mathrm{~g}$ per $100 \mathrm{~g}$ grain.

The partial correlations presented in Table 3 suggest a small and significant $(\mathrm{P}<0.05)$ negative correlation between productivity and grits processing. The correlations between productivity and production of small corn grits and bran showed lower positive values. These data suggest a relationship between higher yield with soft endosperm and mealy grains with greater floury ability, fostering the production of oil and small grits for products that require lower starch particles, such as in brewing and extruding products from corn starch.

Table 3. Partial correlations between industrial and agronomic characteristics, removing the crop stand effect.

\begin{tabular}{lccc}
\hline Response variable & Plant height & Ear height & Grain yield \\
\hline Grits processing & -0.10948 & -0.12896 & -0.35840 \\
& $(0.32450)$ & $(0.24530)$ & $(0.00090)$ \\
Small grits processing & 0.03857 & 0.05421 & 0.26932 \\
& $(0.72920)$ & $(0.62640)$ & $(0.01380)$ \\
Bran processing & 0.08419 & 0.10764 & $(0.30466$ \\
Grain yield & $(0.44920)$ & $0.163270)$ & $(0.00510)$ \\
& 0.13781 & $(0.13400)$ & - \\
\hline
\end{tabular}

The first line show the correlation between variables and the values inside parenthesis are the probability for significance using the $t$-test.

Table 4 exhibits a summary of GCA and SCA and reciprocal effect for each response variable derived from diallel analysis. All response variables showed highly significant treatment effects in GCA; however, with respect to SCA, only the variables yield and crop stand showed significance $(\mathrm{P}<0.05)$.

Table 4. Summary of specific combining ability and general combining ability for each response variable.

\begin{tabular}{lrrrr}
\hline Response variable & \multicolumn{2}{c}{ General combining ability } & \multicolumn{2}{c}{ Specific combining ability } \\
\cline { 2 - 4 } & Mean square & P value & $<0.0000$ & Mean square \\
\hline Plant heights & 0.157967 & $<0.0000$ & 0.013755 & 0.2749 \\
Ear heights & 0.053438 & $<0.0000$ & 0.008665 & $<0.1847$ \\
Crop stands & $1,338.874945$ & $<0.0000$ & 405.907660 & $<0.0000$ \\
Grain yields & $1,832,254.810482$ & 0.0032 & $672,639.130835$ & 0.3253 \\
Grits processing & 38.183010 & 0.0004 & 1.383940 & 0.2369 \\
Small grits processing & 5.025793 & 0.0062 & 6.127420 & 0.3209 \\
Bran processing & 16.999465 & & & \\
\hline
\end{tabular}

When quadratic components of specific and general combining ability, as seen in Table 5, there is a predominance of additive effects for all industrial characteristics as well as plant height and ear insertion height, emphasizing that the plant height showed the highest ratio among the calculated estimates. Concerning yield and harvest stand, both characteristics exhibited a larger non-additive estimate. 
Table 5. Quadratic components of specific and general combining ability.

\begin{tabular}{lrrr}
\hline Response variable & \multicolumn{3}{c}{ Estimates } \\
\cline { 2 - 4 } & \multicolumn{1}{c}{$\widehat{\phi}_{g}^{2}$} & $\widehat{\phi}_{s}^{2}$ & $\widehat{\phi}_{g}^{2} / \widehat{\phi}_{s}^{2}$ \\
\hline Plant heights & 0.008150 & 0.000827 & 9.854897 \\
Ear heights & 0.002615 & 0.000763 & 3.427261 \\
Crop stands & 68.964466 & 102.797703 & 0.670876 \\
Grain yields & $101,791.841751$ & $224,212.490625$ & 0.453997 \\
Grits processing & 1.523717 & 0.563810 & 2.702536 \\
Small grits processing & 0.218828 & 0.099007 & 2.210228 \\
Bran processing & 0.651583 & 0.285481 & 2.282404 \\
\hline
\end{tabular}

These results suggest that the best strategy to secure a productive material is hybridization using parents with high SCA for yield and crop stand and high genotypic values in each parent for the desired industrial characteristics, such as high conversion capability of grains to grits. A similar view as recommended for industrial characteristics should be adopted for plant height and ear insertion height.

Regarding GCA, the parent IAC Nelore was highlighted by its favorable deviation from the other seven parents. IAC Nelore showed superior productivity, according to Table 6 , but lower conversion of grain into grits. However, in Table 7, this parent shows a great aptitude for bran production. Thus this hybrid is recommended for breeding using recurrent selection for general combining ability with the parent HT 9332 as a tester. This tester is interesting because it has a reasonable yield and high conversion of grain into grits. However it is expected that individuals from this cross have good yield and satisfactory production of grits and bran. However, if you want materials with high yield and with high conversion of grain into small grits or bran, the hybrid HT 5392 x HT 392 is the most recommended to line extraction.

Table 6. General combining ability for agronomic characteristics.

\begin{tabular}{lccrr}
\hline Parent & Plant heights $(\mathrm{m})$ & Ear heights $(\mathrm{m})$ & Crop stands (unit) & Grain yields $(\mathrm{kg} / \mathrm{ha})$ \\
\hline IPR 119 & -0.072083 & -0.050139 & -15.888917 & -326.013750 \\
IPR 127 & -0.025971 & -0.015139 & 4.166750 & -471.530417 \\
IAC Nelore & 0.218472 & 0.124304 & 6.999917 & 461.157917 \\
HT 932 & -0.029863 & -0.033471 & -4.444417 & -231.485417 \\
HD 332 & -0.005973 & -0.005696 & -0.333417 & 44.039583 \\
HT 9332 & -0.067638 & -0.035694 & 5.388917 & 215.321250 \\
HT 5392 & -0.041528 & 0.003751 & -6.444417 & 49.916250 \\
HT 392 & 0.024584 & 0.012084 & 10.555583 & 258.594583 \\
\hline
\end{tabular}

Table 7. General combining ability for industrial characteristics.

\begin{tabular}{lccr}
\hline Parent & Grits production & Small grits production & Bran production \\
\hline IPR 119 & -1.410188 & 0.447927 & 1.188425 \\
IPR 127 & 2.799529 & -1.117907 & -1.492858 \\
IAC Nelore & -0.602588 & -0.261187 & 0.523592 \\
HT 932 & 1.033579 & -0.188997 & -0.727542 \\
HD 332 & -0.163238 & 0.394990 & -0.595658 \\
HT 9332 & 0.560379 & 0.033565 & -0.459092 \\
HT 5392 & -1.738138 & 0.389840 & 1.216992 \\
HT 392 & -0.479338 & 0.301768 & 0.346142 \\
\hline
\end{tabular}


However, if the intention is extract lines with high grain yield, good crop stand, according to Table 8, the recommended hybrids are IAC Nelore x HT 932, expecting to extract lines with higher yield and good grits conversion. If it is desired line with higher grain production with high grits production, the hybrid IPR 127 x HD 332 is a good suggestion. However if the intention is a higher oil production or a great small grits conversion the hybrid IPR 119 $\mathrm{x}$ IAC Nelore is the better choice.

\section{Table 8. Specific combining ability for agronomics characteristics.}

\begin{tabular}{lcccccccc}
\hline Genitor & IPR 119 & IPR 127 & IAC Nelore & HT 932 & HD 332 & HT 9332 & HT 5392 & HT 392 \\
\hline IPR 119 & - & -0.480 & 0.041 & 0.392 & -0.380 & -0.060 & -0.043 & 0.108 \\
& & $(-0.012)$ & $(-0.044)$ & $(0.033)$ & $(-0.014)$ & $(-0.028)$ & $(0.013)$ & $(0.051)$ \\
IPR 127 & 2.198 & - & -0.068 & -0.067 & 0.125 & 0.137 & -0.012 & 0.045 \\
& $(285.600)$ & & $(-0.029)$ & $(-0.052)$ & $(0.001)$ & $(0.067)$ & $(-0.002)$ & $(0.026)$ \\
IAC Nelore & -8.302 & -8.690 & - & 0.052 & 0.055 & -0.010 & 0.020 & -0.089 \\
& $(-384.509)$ & $(-367.422)$ & & $(0.062)$ & $(0.051)$ & $(0.031)$ & $(0.015)$ & $(-0.087)$ \\
HT 932 & 6.143 & -2.246 & 16.921 & - & -0.034 & 0.061 & 0.022 & -0.074 \\
& $(667.575)$ & $(-16.499)$ & $(447.263)$ & & $(-0.038)$ & $(0.052)$ & $(0.013)$ & $(-0.072)$ \\
HD 332 & -14.301 & 2.976 & 13.810 & 1.921 & - & -0.082 & 0.055 & 0.032 \\
& $(-521.861)$ & $(408.936)$ & $(560.258)$ & $(-355.079)$ & & $(-0.062)$ & $(0.038)$ & $(0.023)$ \\
HT 9332 & 17.643 & -6.413 & 4.087 & -3.468 & -9.246 & - & -0.034 & -0.013 \\
& $(-114.622)$ & $(-331.786)$ & $(297.086)$ & $(169.270)$ & $(-180.916)$ & -0.037 & $(-0.098)$ & $(0.037)$ \\
HT 5392 & -10.524 & 6.754 & -9.079 & 2.698 & 8.587 & -11.468 & - & -0.009 \\
& $(-563.227)$ & $(23.210)$ & $(-311.199)$ & $(-76.666)$ & $(391.590)$ & $(63.002)$ & $(0.021)$ \\
HT 392 & 7.143 & 5.421 & -8.746 & -21.968 & -3.746 & 8.865 & 13.032 & - \\
& $(631.045)$ & $(-8.039)$ & $(271.477)$ & $(-865.864)$ & $(-302.929)$ & $(223.970)$ & $(593.295)$ & \\
\hline
\end{tabular}

In the upper diagonal the first line value is plant height and in parenthesis the ear height. In the lower diagonal inside parenthesis are the crop stand and outside the grain yield values.

All the seven response variables were evaluated as significant for the hybrid trait effect $(\mathrm{P}<0.05)$. The Griffing analyses indicated only the response variables grain yield and crop stand as significant for specific combining ability at the predetermined level, however all the seven response variables present a significant general combining ability. The partial correlation analyses shown have significant low intensity negative correlation between grits production and grain yield. Concerning to breeding programs, the hybrids IPR 119 x HT 392 and IAC Nelore x HD 332 are recommended to pure line extraction and for a recurrent selection program the parent IAC Nelore should be to the point.

\section{REFERENCES}

Cabral PDS, Amaral AT Jr, Vieira HD, Santos JS, et al. (2013). Genetic effects on seed quality in diallel crosses of popcorn. Cienc. Agr. Lav. 37: 502-511.

Castro MVL, Naves MMV, Oliveira JP and Oliveira Froes L (2009). Rendimento industrial e composição química de milho de alta qualidade proteica em relação a híbridos comerciais. Pesq. Agropec. Trop. 39: 233-242.

Fasoulas AC (1983). Rating cultivars and trials in applied plant breeding. Euphytica 32: 939-943.

Gomes MDS, Von Pinho EVD, Von Pinho RG and Vieira MDGGC (2000). Efeito da heterose na qualidade fisiológica de sementes de milho. Rev. Bras. Sem. 22: 7-17.

Griffing B (1955). Generalised treatment of the use of diallel crosses in quantitative inheritance. Heredity 10: 31-50.

Mittelmann A, Miranda Filho JBD, Lima GJMMD, Hara-Klein C, et al. (2006). Análise dialélica do teor de óleo em milho. Rev. Bras. Agr. 12: 139-143.

Moterle LM, Braccini AL, Scapim CA, Pinto RJB, et al. (2012). Combining ability of popcorn lines for seed quality and agronomic traits. Euphytica 185: 337-347.

Paini JN, Cruz CD, Delboni JS and Scapim CA (1996). Capacidade combinatória e heterose em cruzamentos intervarietais 
de milho avaliados sob as condições climáticas da Região Sul do Brasil. Ceres 43: 288-300.

Pfann AZ, Faria MV, Andrade AA, Nascimento IRD, et al. (2009). Capacidade combinatória entre híbridos simples de milho em dialelo circulante. Cienc. Rural 39: 635-641.

Rodrigues F, Von Pinho RG, Albuquerque CJB, Faria Filho EM, et al. (2009). Capacidade de combinação entre linhagens de milho visando à produção de milho verde. Bragantia 68 : 75-84.

Scapim CA, Pacheco CAP, Tonet A, Braccini ADLE, et al. (2002). Análise dialélica e heterose de populações de milho pipoca. Bragantia 61: 219-230.

Teixeira FF, Souza IRPD, Gama EEGE, Pacheco CAP, et al. (2001). Avaliação da capacidade de combinação entre linhagens de milho doce. Cienc. Agr. 25: 483-488.

Teixeira FF, Souza IRPD, Gama EEGE, Pacheco CAP, et al. (2001). Avaliação da capacidade de combinação entre linhagens de milho doce. Cienc. Agr. 25: 483-488.

Ünay A, Konac C and Basal H (2004). Inheritance of grain yield in a half-diallel maize population. Turk. J. Agr. Forest. 28: $239-244$ 